\title{
Contributo para o estudo do povoamento rural de Igaedis (civitas Igaeditanorum) através de um mapa de usos potenciais da terra (MUPT)*
}

\section{A contribution towards the study of rural settlement dynamics in Igaedis (civitas Igaeditanorum) with a potential land use map}

\author{
Sofia Lacerda ${ }^{1}$ \\ Marcos Osório ${ }^{2}$ \\ Pedro C. Carvalho ${ }^{3}$ \\ Universidade de Coimbra
}

\section{RESUMO}

Para compreendermos a ocupação do território em torno de Idanha-a-Velha (capital da civitas Igaeditanorum) e as dinâmicas de povoamento que aí se desenvolveram, construímos um Mapa de Usos Potenciais da Terra que cruzámos com os assentamentos rurais romanos identificados em trabalhos de prospeção intensiva. Esta cartografia digital arqueológica representa uma metodologia inovadora raramente aplicada em território português. Distingue-se da cartografia tradicional de solos pelo facto de ser contextual, permitindo ao investigador produzi-lo em função das particularidades do período a estudar.

\section{SUMMARY}

To understand the occupation of the territory around Idanha-a-Velha (civitas Igaeditanorum capital) and its settlement dynamics, we built a Potential Land Use Map articulated with the Roman rural sites identified during

\footnotetext{
"Na origem deste trabalho encontra-se uma dissertação de Mestrado em Arqueologia e Território apresentada por Sofia Lacerda em 2017, na Faculdade de Letras da Universidade de Coimbra. Este trabalho inscreve-se ainda no quadro do Projeto de Investigação Plurianual (aprovado pela Direção Geral do Património Cultural: 2016-2019) intitulado IGAEDIS. Da civitas Igaeditanorum à Egitânia. A construção e evolução da cidade e a definição dos seus territórios da Época Romana até à doação dos Templários (séculos I a XII), coordenado por Pedro C. Carvalho (FLUC) e Catarina Tente (FCSH/UNL) e com o apoio do Município de Idanha-a-Nova.

1 a.sofialacerda@hotmail.com / ORCID iD: https://orcid. org/0000-0002-0182-2474

2 arkmarcos@hotmail.com / ORCID iD: https://orcid. org/0000-0003-4340-4614

3 pedrooak@gmail.com / ORCID iD: https://orcid.org/00000003-3749-3542
}

intensive field surveys. Digital archaeological cartography provides us with innovative methods which differ from traditional soil cartography because they involve historical context and meaning, allowing researchers to produce a map with the particularities of each historical period in mind.

\section{RESUMEN}

Para poder comprender la ocupación del territorio en torno de Idanha-a-Velha (capital de la civitas Igaeditanorum) y las dinámicas del poblamiento que ahí se desarrollaron, construimos un Mapa de Usos Potenciales de la Tierra que cruzamos con los asentamientos rurales romanos identificados en trabajos de prospección intensiva. Esta cartografía digital arqueológica representa una metodología innovadora que raramente ha sido aplicada en territorio portugués. Se distingue de la cartografía tradicional de los suelos por el hecho de ser contextual, permitiendo al investigador producir el mapa en función de las particularidades del período estudiado.

PALAVRAS-CHAVE: Lusitânia Romana; Paisagem Rural; SIG; Idanha-a-Velha.

KEY WORDS: Roman Lusitania; Rural Landscape; GIS; Idanha-a-Velha.

PALABRAS CLAVE: Lusitania romana; paisaje rural; SIG; Idanha-a-Velha.

COMO CITAR ESTE ARTÍCULO / CITATION: Lacerda, S., Osório, M. y Carvalho, P. C. 2019: "Contributo para o estudo do povoamento rural de Igaedis (civitas Igaeditanorum) através de um mapa de usos potenciais da terra (MUPT)", Archivo Español de Arqueología 92, 213-228. https://doi.org/10.3989/aespa.092.019.011

Copyright: () 2019 CSIC. Este es un artículo de acceso abierto distribuido bajo los términos de una licencia de uso y distribución Creative Commons Reconocimiento 4.0 Internacional (CC-by 4.0). 


\section{O MAPA DE USOS POTENCIAIS DA TERRA EM TORNO DE IGAEDIS}

Uma das formas de estudar o mundo rural romano, nomeadamente as questões relacionadas com a produção agrícola e as estratégias locacionais, poderá ser através da criação de Mapas de Usos Potenciais da Terra. Os MUPT são um tipo de cartografia digital que nos permite analisar os usos prováveis da terra num determinado período. Produzido por arqueólogos, distinguese da cartografia tradicional de solos na medida em que possui uma dimensão histórica, obtida por meio de uma ponderação contextual dos diferentes critérios utilizados para avaliar o uso da terra (Currás Refojos 2014; Parcero Oubiña 2002; Fábrega Álvarez et alii 2005; Orejas Saco del Valle 1996; Romero Perona 2015).

A ideia de criar um MUPT para Idanha-a-Velha resultou da possibilidade de o ensaiarmos na área em torno de uma capital de civitas (a civitas Igaeditanorum - Fig. 1) cujo povoamento rural romano era bem conhecido. Com efeito, a nossa área de trabalho foi em grande medida ditada pelos sítios arqueológicos identificados aquando de prospeções intensivas levadas a cabo, nos finais do século passado, por José Ruivo, Luís Fernandes e Pedro C. Carvalho.

A primeira etapa para a criação de um MUPT consiste na recolha de dados que nos permitam avaliar a potencialidade da terra. Para isso recorreu-se a diversa bibliografia específica sobre a temática, a cartografia variada, à fotografia aérea e a uma diversidade de ferramentas SIG capazes de processar alguma dessa informação. Os critérios que nos permitem analisar o potencial da terra são múltiplos e não são fixos, ainda que muitos se repitam nos diversos estudos que existem sobre esta matéria. Para a criação em ambiente SIG do MUPT de Idanha utilizámos os

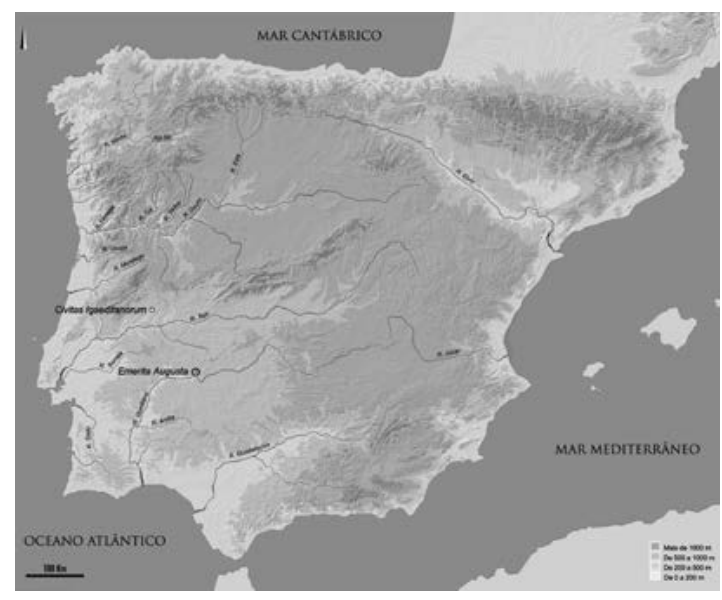

Figura 1. Localização de Idanha-a-Velha no contexto peninsular (J. L. Madeira). seguintes: tipos de solo (informação consultada na Carta de Solos de Portugal); a presença de afloramento rochoso, identificado por fotointerpretação; a morfologia do relevo, baseada no MDT; e a exposição solar, calculada com base nos valores altimétricos do território (a metodologia de construção deste mapa é discutida com detalhe em Lacerda 2018). A escolha destes parâmetros foi em grande medida marcada pela disponibilidade de dados e pela nossa escala de trabalho. $\mathrm{O}$ facto de dispormos de uma reduzida área de estudo fez com que alguns critérios com uma representatividade homogénea em todo o território, como por exemplo o clima ou o regime hídrico, não tivessem sido aplicados, pois a esta escala não funcionariam como fator diferenciador.

Às variáveis resultantes do cruzamento desses critérios fez-se depois corresponder uma classificação de uso potencial da terra: i) classe de uso potencial extensivo máximo, ii) classe de uso potencial extensivo médio, iii) classe de uso potencial intensivo e $i v$ ) classe de uso potencial nulo. As duas primeiras classes equivalem àquelas áreas do nosso mapa onde poderia ser praticada uma agricultura de tipo extensivo, associada a solos ligeiros, bem drenados e sem profundidade, depreendendo-se o uso de uma tecnologia agrária não muito elaborada; estas classes distinguem-se na medida em que o uso potencial extensivo médio pressupõe maiores dificuldades produtivas, provocadas pelas condições naturais envolventes, do que o uso potencial extensivo máximo. À classe de uso intensivo corresponderiam as zonas onde se poderia praticar uma agricultura de tipo intensivo, caracterizada pela existência de solos pesados, muito nutridos e alagados, que exigem maior conhecimento da terra e outra tecnologia; a classe de uso potencial nulo delimita as áreas onde a prática agrícola não teria grande viabilidade. Os trabalhos que se têm vindo a desenvolver sobre o uso potencial da terra utilizam diferentes tipos de classes, sendo o trio intensivo, extensivo e nulo o mais adotado (Currás Refojos 2014; Parcero Oubiña 2002; Fábrega Álvarez et alii 2005) ${ }^{4}$. Ainda que a terminologia que define as classes de um mapa de usos potenciais seja uma escolha do investigador, consideramos que esta se deve adaptar às características do território em estudo e respetiva escala.

Fazer corresponder a combinação dos diferentes critérios considerados a uma classe específica de uso potencial da terra não é uma tarefa simples e encerra sempre alguma subjetividade. Não existindo uma fórmula que nos permita saber, sem margem para dúvidas, quais os fatores que mais determinam a aptidão

\footnotetext{
4 Ver outras opções como por exemplo Orejas Saco del Valle 1996.
} 


\begin{tabular}{|c|c|c|c|c|}
\hline Parâmetros / Classes & $\begin{array}{l}\text { Potencial extensivo } \\
\text { máximo }\end{array}$ & $\begin{array}{l}\text { Potencial extensivo } \\
\text { médio }\end{array}$ & Potencial intensivo & Potencial nulo \\
\hline Declive & $0-15 \%$ & $15-30 \%$ & $0-15 \%$ & $>30 \%$ \\
\hline Exposição solar & Soalheiro & Sombrio & Soalheiro & - \\
\hline Solos & $\begin{array}{l}\text { Solos podzolizados; } \\
\text { solos argiluviados }\end{array}$ & $\begin{array}{l}\text { Solos incipientes; } \\
\text { solos litólicos }\end{array}$ & $\begin{array}{l}\text { Solos incipientes da } \\
\text { subordem } \\
\text { aluviossolos; solos } \\
\text { incipientes da } \\
\text { subordem } \\
\text { coluviossolos }\end{array}$ & $\begin{array}{l}\text { Zonas de } \\
\text { afloramento rochoso; } \\
\text { área social; solos } \\
\text { hidromórficos }\end{array}$ \\
\hline
\end{tabular}

Figura 2. Classes do MUPT.

agrícola da terra, resta-nos procurar cruzar de forma ponderada os diferentes critérios.

As relações entre os parâmetros definidos e as classes estabelecidas no MUPT de Idanha resumem-se na tabela da figura 2.

Mediante uma operação de álgebra de mapas calculada no software QGIS 2.14 Essen, utilizado durante todo o processo de construção desta cartografia, foi gerado o Mapa de Usos Potenciais da Terra para as terras em torno de Igaedis (Fig. 3).
O mapa da figura 3 é uma representação em formato vetorial das manchas de distribuição de cada classe de uso potencial da terra. As áreas tintadas a cinzento claro correspondem à classe de uso potencial extensivo máximo (correspondendo a $35 \%$ da área total deste MUPT), distribuindo-se por uma faixa diagonal no sentido sudoeste-nordeste do mapa. A classe de uso potencial extensivo médio (45\%) encontra-se representada a cinzento escuro, dispersa de modo generalizado um pouco por todo o âmbito de

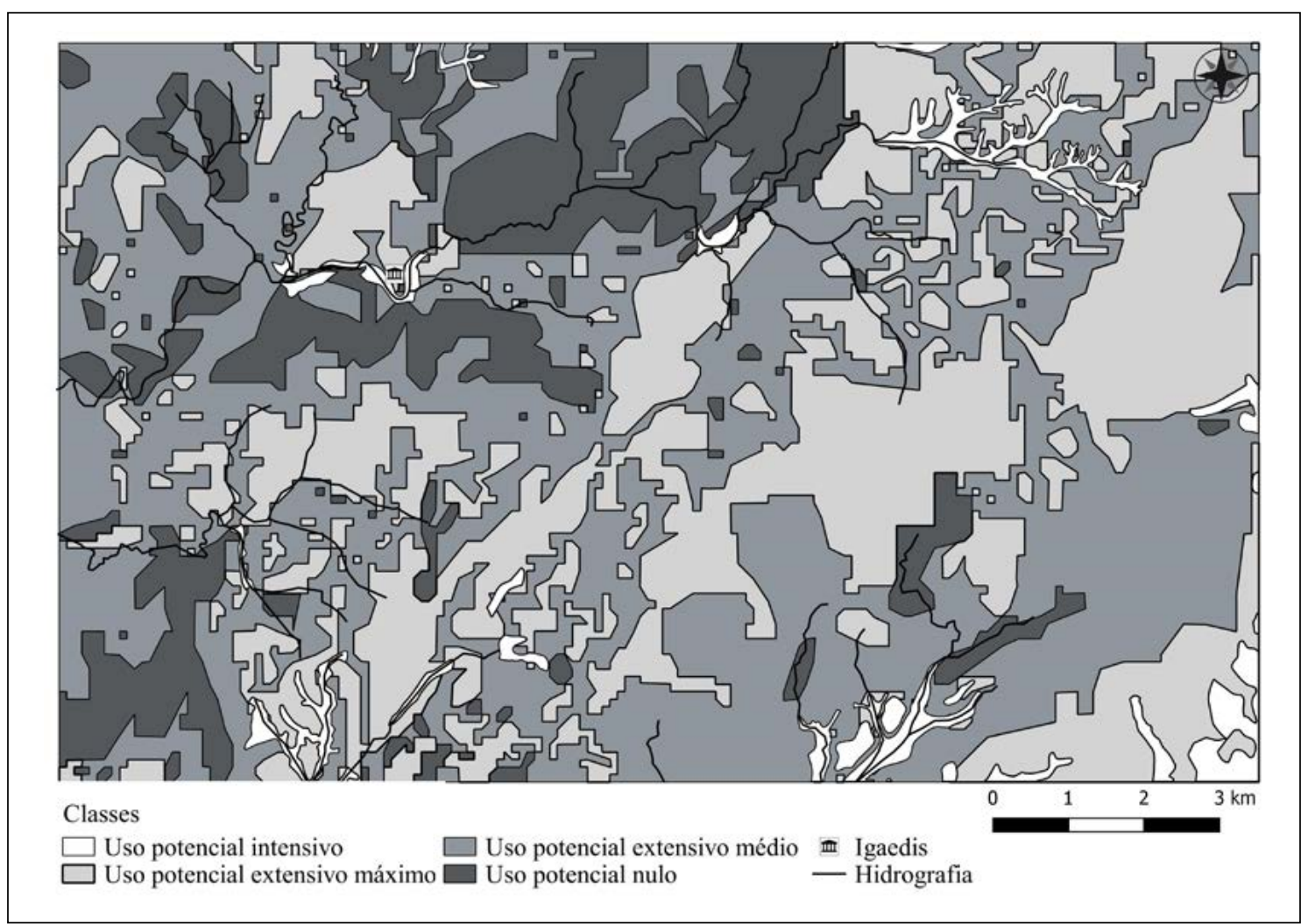

Figura 3. Mapa de usos potenciais da terra (S. Lacerda). 
estudo, intercalando-se com as outras. A branco encontramos aquelas áreas às quais se fez corresponder a classe de uso potencial intensivo (4\%), sendo esta menos representativa e cingindo-se às zonas baixas $\mathrm{e}$ aluvionares, junto a linhas de água. Finalmente, a classe de uso potencial nulo (16\%), está representada a negro, destacando-se a sua presença essencialmente na parte mais setentrional e ocidental do mapa.

A construção de um MUPT não foi entendida como um fim em si mesmo. Todo este processamento informático visou o cruzamento do meio físico com as evidências arqueológicas relativas ao povoamento rural em torno da cidade - caso contrário não teria utilidade para o propósito do nosso estudo. É igualmente importante compreender bem o conceito subjacente ao MUPT: este não constitui um retrato exato do que foram os usos da terra; trata-se antes de uma proposta de representação de um cenário produtivo provável, ou seja, de uma realidade interpretada. No entanto, apesar das limitações conhecidas, esta cartografia apresenta notórias vantagens sobre as tradicionais cartas de uso do solo (Lacerda 2018).

Neste trabalho pretendemos, sobretudo, utilizar o MUPT de Idanha como um recurso que, cruzado com os sítios romanos conhecidos na área, nos permita estabelecer possíveis relações entre o meio natural e o povoamento rural romano, através de um conjunto de análises espaciais mais à frente desenvolvidas. Importanos de igual modo detetar e perceber padrões na forma como os núcleos de povoamento se instalaram, conjeturando sobre os limites das suas propriedades, qual a relação destas com a terra disponível e que tipo de uso potencial lhe estava associado, se há uma preferência (ou se existem diferenças) por certos tipos de terra disponível ou por distintos espaços (combinação de terras) consoante também os distintos tipos de sítios, tentando ainda perceber qual a lógica da disposição dos núcleos rurais entre si, e destes relativamente à cidade capital, bem como à estrutura viária que aí se desenhou.

\section{A TERRA E O POVOAMENTO RURAL ROMANO EM TORNO DE IGAEDIS}

Os núcleos de povoamento rural assinalados neste estudo resultaram sobretudo das prospeções intensivas efetuadas numa área que se estende essencialmente a sul de Idanha-a-Velha (Fig. 4 e 10), durante as quais foi possível identificar, numa área com c. 23 $\mathrm{km}^{2}$, um total de 41 sítios da Época Romana ${ }^{5}$. Foram

\footnotetext{
${ }^{5}$ Este trabalho foi elaborado por José Ruivo, Luís Fernandes e Pedro C. Carvalho, em 1991, no âmbito de um seminário da licenciatura em História variante de Arqueologia da Faculdade
}

ainda considerados outros sítios romanos localizados por Vitor Pedrosa ${ }^{6}$, Joaquim Baptista (1998) e Pilar Reis (2013), que nos permitiram completar o quadro do povoamento sobretudo nas áreas contíguas a norte da anterior. Foi assim possível assinalar, no total, 99 sítios na área compreendida pela nossa cartografia.

Cada um destes sítios identificado em prospeção foi objeto de classificação tipológica - tarefa que não foi fácil e nem sempre consensual. Não obstante as dificuldades que esta classificação encerra, avançámos com propostas feitas a partir de trabalho efetivo de campo e com base em parâmetros que têm sido estabelecidos para o efeito (Alarcão 1998; Carvalho 2004): referimonos sobretudo às áreas de dispersão e também à quantidade e qualidade dos materiais observados à superfície.

A opção pela distinção tipológica dos sítios constitui, a nosso ver, um passo importante para este tipo de estudos sobre o povoamento rural. Não hierarquizar ou não classificar os sítios arqueológicos ou então utilizar termos vagos, do tipo "habitat", "mancha de ocupação" ou "estação de superfície", desprovidos de qualquer significado social ou cultural, revela-se pouco operacional para este tipo de análises espaciais. Ainda que certas classificações tipológicas possam revelar-se na prática duvidosas, nomeadamente face à ação diferenciada de processos pós-deposicionais, importa efetuá-las mediante a observação direta dos vestígios de superfície e a aplicação de critérios uniformes, podendo assim distinguir-se no terreno o que pode configurar, por exemplo, uma villa ou um casal - núcleos de povoamento rural com dimensões socioeconómicas manifestamente distintas. Quando se abordam as questões em torno da propriedade e exploração da terra, estas classificações tipológicas justificam-se na medida em que a diferença entre uma villa e um casal reside, desde logo, na escala de produção, estando esta, por sua vez, dependente também da dimensão da propriedade e das características das terras.

Para testar o nosso mapa tivemos em conta sobretudo o conjunto de sítios onde estas classificações tipológicas foram ensaiadas e que correspondem, grosso modo, àqueles identificados aquando das prospeções

de Letras da Universidade de Coimbra. Mais tarde, foi apresentado no $3^{\circ}$ Congresso Peninsular de História Antiga (Vitoria/ Gasteiz, 1994). Porém, as atas desse encontro científico nunca chegaram a ser publicadas. Em outubro de 2016 o assunto voltou a ser abordado pelos autores desse trabalho académico e por Sofia Lacerda num colóquio de homenagem a Francisco Tavares Proença (Museu Arqueológico do Carmo, Lisboa), intitulado "Carta arqueológica do distrito de Castelo Branco, contributos para uma revisão cem anos depois". Uma interpretação dos resultados deste trabalho de prospeção intensiva foi antes apresentada por Jorge de Alarcão (1999).

6 Trabalho elaborado em 1996, no âmbito de um seminário da licenciatura em História variante de Arqueologia da Faculdade de Letras da Universidade de Coimbra. 
intensivas - aspeto importante, na medida em que esta metodologia de campo é capaz de detetar, para além dos sítios de maior entidade, aqueles sítios que se revelam à superfície por pequenas manchas de materiais, registando igualmente as áreas vazias de povoamento. Deste modo, se as condições de visibilidade do solo o permitirem, é possível recuperar uma amostragem suficientemente representativa do padrão de povoamento antigo.

Dos 99 sítios cartografados ${ }^{7}$ (Fig. 4) excluímos de certas análises aqueles cuja funcionalidade parece não estabelecer qualquer relação com a posse/propriedade da terra, nomeadamente as pequenas construções rurais (identificadas aqui como tuguria) que constituiriam dependências (abrigos, arrumos ou outras instalações espacialmente dissociadas de uma pars rustica) de núcleos rurais de maior entidade. As análises espaciais efetuadas tiveram assim essencialmente em conta as villae e os casais, enquanto "cabeças" de propriedade.

\footnotetext{
${ }^{7}$ Relativamente à dissertação de mestrado que se encontra na origem deste estudo, foi efetuada uma revisão dos sítios ar-
}

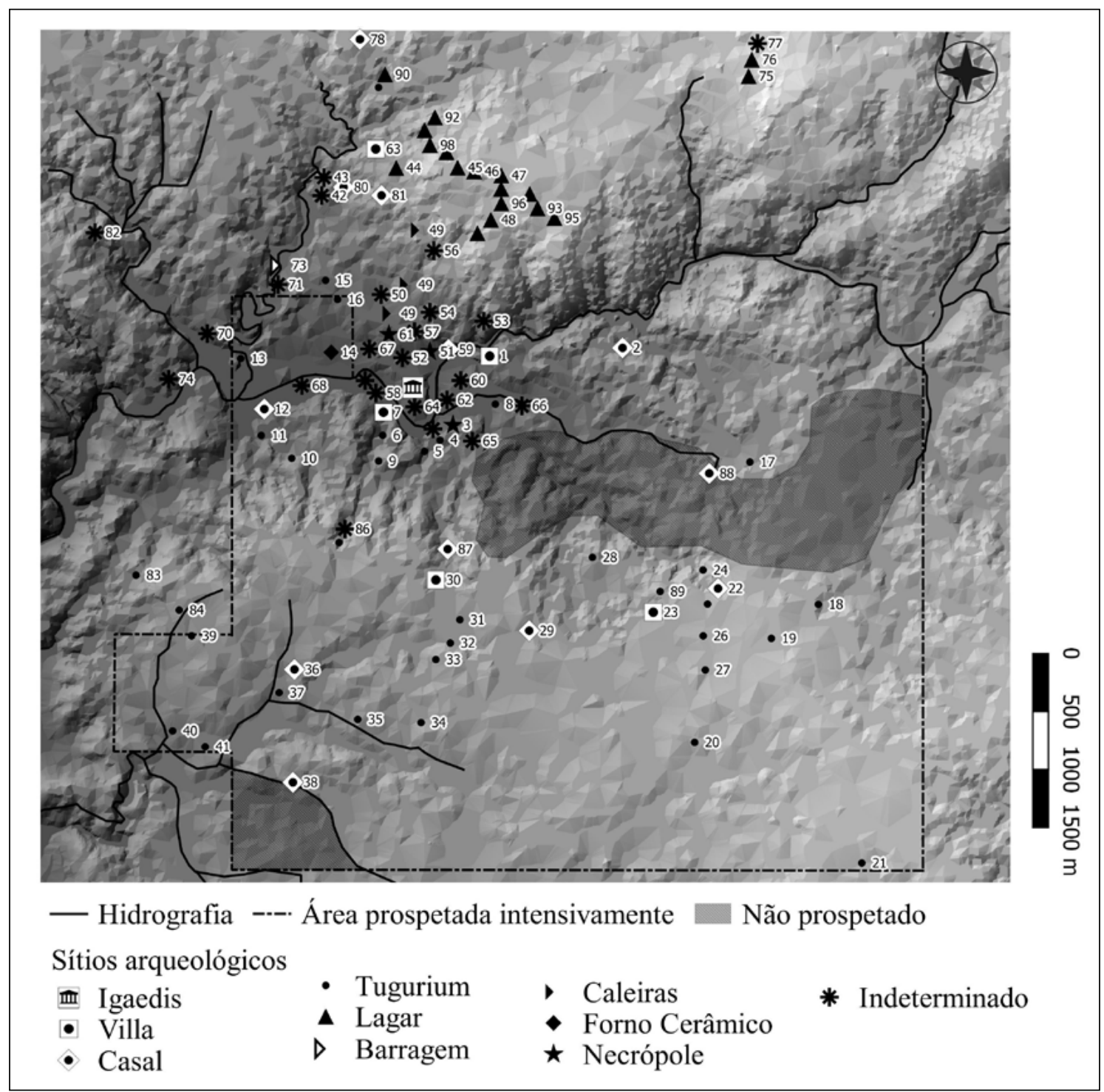

Figura 4. Localização dos sítios do Período Romano na área estudada (cf. Anexo I, Fig. 11) (S. Lacerda). 
Noutras abordagens analíticas foram considerados outros tipos de sítios (como é o caso de um forno cerâmico, para além dos tuguria), na medida em que estes se inscrevem igualmente na dinâmica do povoamento rural em torno de Igaedis. Os sítios de tipologia indeterminada foram cartografados, mas não englobados nestas análises espaciais - alguns, revelados por escassas tegulae e/ou cerâmicas comuns, muito dispersas, podem até denunciar a presença de espaços funerários, como aqueles que se situam imediatamente a norte da cidade e que ladeariam a via que seguia no sentido da Serra da Estrela; outros, talvez denunciem a presença de simples casebres, posicionados no entorno imediato de Igaedis ou constituindo mesmo a extensão máxima da própria cidade ${ }^{8}$. Os lagares escavados na rocha também ficaram fora das análises espaciais. Tal deve-se à indefinição cronológica deste tipo de estruturas, mesmo quando associadas, aparentemente, a sítios romanos ${ }^{9}$. Seja como for, estes foram cartografados, sendo muito frequentes nesta área, em particular entre Idanha-a-Velha e Monsanto (Henriques et alii 2008). O seu aparecimento a norte do curso do rio Ponsul prende-se desde logo com o facto de esta ser uma zona granítica, enquanto que a sul deste rio o substrato geológico é xistoso.

Em 1991, os sítios identificados foram cartografados unicamente através de um ponto/coordenada e não através do levantamento de vários pontos georreferenciados que desenhassem essas manchas de dispersão mediante polígonos. De todo o modo, as medidas de superfície então registadas resultaram de cálculos no terreno. Estas áreas de dispersão, articuladas com o tipo de materiais observados à superfície, permitemnos ter uma ideia da possível dimensão e natureza das estruturas soterradas, propondo assim a sua classificação tipológica diferenciada. Todavia, se temos indicadores que nos permitem distinguir com alguma segurança, por exemplo, o espaço edificado de uma villa ou de um casal, como poderemos estimar a extensão e configuração dos seus respetivos fundi? As análises espaciais em ambiente SIG, nomeadamente o cálculo de áreas de influência, ainda que sejam meros exercícios teóricos, podem ajudar-nos a abordar esta problemática, sobretudo quando trabalhamos pa-

\footnotetext{
${ }^{8}$ Nesta área adjacente à cidade é particularmente difícil individualizar sítios arqueológicos em prospeção. Uma certa continuidade de vestígios de superfície leva-nos a alertar para a possibilidade de estarmos a distinguir sítios que, na realidade, correspondem a um só.

9 Para além da sua indefinição funcional: seriam lagares de azeite e/ou de vinho? Se, por um lado, parecem poder associarse mais à produção de vinho, sobretudo aqueles que poderão ser claramente identificados como calcatorium, não podemos deixar de referir que as características edafo-climáticas desta região parecem ser mais propícias ao cultivo da oliveira.
}

drões de povoamento resultantes de prospeções intensivas.

Essas prospeções, todavia, não resolvem o problema da cronologia de ocupação de cada sítio - só a escavação é que poderá proporcionar esse tipo de informação. Ao classificarmos os 99 sítios registados como pertencendo genericamente à Época Romana estamos a localizar num mesmo mapa todos os sítios, partindo do princípio - não comprovado - de que todos foram contemporâneos e que de algum modo se relacionaram. Contudo, a ocupação do espaço e a configuração das propriedades foi um processo dinâmico e evolutivo. Ao longo de cerca de cinco séculos foram seguramente surgindo e desaparecendo núcleos rurais, com a consequente reconfiguração contínua da paisagem rural.

Para melhor compreendermos a orgânica do povoamento de Idanha definimos as áreas de influência dos assentamentos mediante buffers e polígonos de Thiessen, sobrepostos ao MUPT. Esta análise contou também com a criação de territórios de marcha. Através destas ferramentas procurámos compreender a problemática relativa à localização preferencial dos sítios tendo em conta os usos potenciais da terra, bem como a relação existente entre os diferentes tipos de núcleos rurais e entre estes e a propriedade que teriam sob seu domínio.

\subsection{VILLAE}

Nas imediações de Igaedis foram identificadas cinco villae ${ }^{10}$. Face à impossibilidade de determinar a configuração exata ou a extensão real dos fundus, foram calculados buffers a partir de cada uma destas villae. $\mathrm{O}$ exercício consiste num cálculo euclidiano a partir de um ponto central, com um determinado raio de distância fixa, gerando zonas geométricas circulares, projetando a denominada área teórica de influência (Mano 2012: 23; Osório e Salgado 2018: 41).

Os buffers criados foram calculados tendo em consideração a proposta de Jorge de Alarcão (1999: 34), segundo a qual o fundus de uma villa poderia rondar os 100 hectares. Para encontrarmos o raio que irá delimitar a circunferência, a partir desta medida de área, recorremos à seguinte expressão matemática: $\pi \times \mathrm{r}^{2}$.

Na figura 6 observam-se as manchas de usos potenciais abrangidas pelo domínio de influência de cada propriedade. Resumimos essa informação na tabela da figura. 5.

${ }^{10}$ As villae são as seguintes: $\mathrm{n}^{\mathbf{0}} 1$ : Veiga $\mathrm{I} ; \mathrm{n}^{\circ}$ 7: Olival das Almas; $n^{\circ}$ 23: Curral das Lagoas; $n^{\circ}$ 30: Quartos 1; $n^{\circ}$ 63: Terra da Maria de Campo. 


\begin{tabular}{|c|l|}
\hline $\begin{array}{c}\text { Villae } \\
\text { (n. })\end{array}$ & \multicolumn{1}{|c|}{ Domínio de influência } \\
\hline 1 & $\begin{array}{l}\text { 46\% de terras de uso potencial extensivo médio; 24\% de terras de uso potencial nulo; 24\% de uso } \\
\text { potencial extensivo máximo; 6\% de terras de uso potencial intensivo }\end{array}$ \\
\hline 7 & $\begin{array}{l}27 \% \text { de terras de uso potencial extensivo médio; 16\% de terras de uso potencial extensivo máximo; } \\
37 \% \text { de terras de uso potencial nulo; } 20 \% \text { de terras de uso potencial intensivo }\end{array}$ \\
\hline 23 & $\begin{array}{l}77 \% \text { de terras de uso potencial extensivo médio; 17\% de terras de uso potencial nulo; 6\% de terras de } \\
\text { uso potencial extensivo máximo }\end{array}$ \\
\hline 30 & $\begin{array}{l}\text { 47\% de terras de uso potencial extensivo médio; } 40 \% \text { de terras de uso potencial extensivo máximo; } \\
13 \% \text { de terras de uso potencial nulo }\end{array}$ \\
\hline 63 & $\begin{array}{l}\text { 63\% de terras de uso potencial extensivo médio; 28\% de uso potencial nulo; } 9 \% \text { de uso potencial } \\
\text { extensivo máximo }\end{array}$ \\
\hline
\end{tabular}

Figura 5. Usos potenciais da terra contidos na área de influência das villae (S. Lacerda).

Perante estes dados, verificamos que praticamente todas as villae analisadas incluem no seu domínio de influência uma esmagadora maioria de terras de uso potencial extensivo, com predomínio do uso potencial médio relativamente ao máximo. Por sua vez, a classe menos representada nos domínios de influência das villae é a de uso potencial intensivo, presente apenas nas villae $\mathrm{n}^{\circ} 1$ e 7 - classe já por si rara na região (na área do MUPT representa 4\% do total). Sublinhe-se ainda o facto de todas as villae apresentarem (em maior ou menor percentagem) áreas de uso potencial nulo, a maioria com valores acima dos $20 \%$.

Da análise da figura 6 deduz-se que as villae de Idanha possuíram terras com usos potencialmente distintos e que se contrabalançam. Tal remete para a ideia de que o fundus de uma villa incluiria uma diversidade de recursos e atividades que se complementariam, dando corpo a uma exploração verdadeiramente agropecuária. À agricultura praticada nos solos mais rentáveis, onde talvez predominasse o cultivo do cereal de sequeiro e do olival, juntar-se-ia assim a pastorícia, a criação de gado e a silvicultura nas terras com menor potencial.

A proximidade ou mesmo sobreposição das áreas teóricas de influência de algumas villae e casais, faznos levantar a possibilidade de, em alguns casos, estarmos a individualizar como propriedade autónoma sítios classificados como casais que poderiam antes corresponder a anexos de uma cabeça de propriedade. Estão nesta situação as villa $\mathrm{n}^{\circ} 1$ e o casal $\mathrm{n}^{\circ}$ 59; a villa $\mathrm{n}^{\circ} 23$ e o casal $\mathrm{n}^{\circ} 22$; a villa $\mathrm{n}^{\circ} 30$ e o casal $\mathrm{n}^{\circ} 87$; e a villa $\mathrm{n}^{\circ} 63$ e os casais $\mathrm{n}^{\circ} 80$ e 81 .

Numa outra abordagem calcularam-se os polígonos de Thiessen (Fig. 6). Este exercício gera áreas poligonais em que o respetivo limite territorial corresponde a uma zona equidistante entre os lugares considerados centrais (neste caso as villae) (Osório e Salgado 2018: 43). Esta análise espacial é uma das mais utilizadas na arqueologia (Wheatley e Gillings 2002: 149). Se, por um lado, projetámos buffers para aferir essencialmente os usos prováveis da terra no fundus de cada villa, por outro, ensaiámos a aplicação dos polígonos de Thiessen para melhor compreender as possíveis relações entre as villae e os pequenos sítios dispersos, provavelmente subsidiários destes núcleos centrais, como é o caso dos tuguria que, como vimos, poderiam funcionar como locais de apoio à agropecuária ${ }^{11}$.

$\mathrm{O}$ resultado desta operação permitiu-nos conjeturar sobre quais os tuguria que estariam na dependência de cada villa. Assim, no mesmo mapa (Fig. 6), podemos verificar a existência de relações entre:

a) villa $\mathrm{n}^{\mathrm{o}} 1$ e o tugurium $\mathrm{n}^{\circ} 8$, possibilidade ratificada pelo buffer;

b) villa $\mathrm{n}^{\mathrm{o}} 7$ e os tuguria $\mathrm{n}^{\circ} 4,5,6,9$, possibilidade ratificada pelo buffer;

c) villa $\mathrm{n}^{\circ} 23$ e os tuguria $\mathrm{n}^{\circ} 20,27,28$ e 89, ao passo que o buffer nos remete para os tuguria $\mathrm{n}^{\circ} 24$, 25, 26 e 89;

d) villa $\mathrm{n}^{\mathrm{o}} 30$ e os tuguria $\mathrm{n}^{\circ} 31,32,33$ e 85, ficando excluído da área definida pelo buffer os últimos dois;

e) finalmente, na área de influência estipulada pelos polígonos de Thiessen da villa $\mathrm{n}^{\circ} 63$ não se registam tuguria; porém na área delimitada pelo buffer aparece incluído o tugurium $\mathrm{n}^{\mathbf{0}} 79$.

$\mathrm{O}$ ensaio dos polígonos de Thiessen permite-nos ainda observar o seguinte: $i$ ) as villae distribuem-se de modo regularmente espaçado pelo território, numa cadência que evita a sobreposição dos territórios de exploração entre si, mas que, em alguns casos, colide com

\footnotetext{
11 Em termos topográficos constatou-se que estes lugares, revelados à superfície (em áreas com poucas centenas de $\mathrm{m}^{2}$ ) por escassas tegulae e cerâmicas comuns, se localizavam quase sempre no topo de pequenos outeiros, claramente expostos na paisagem imediatamente envolvente.
} 


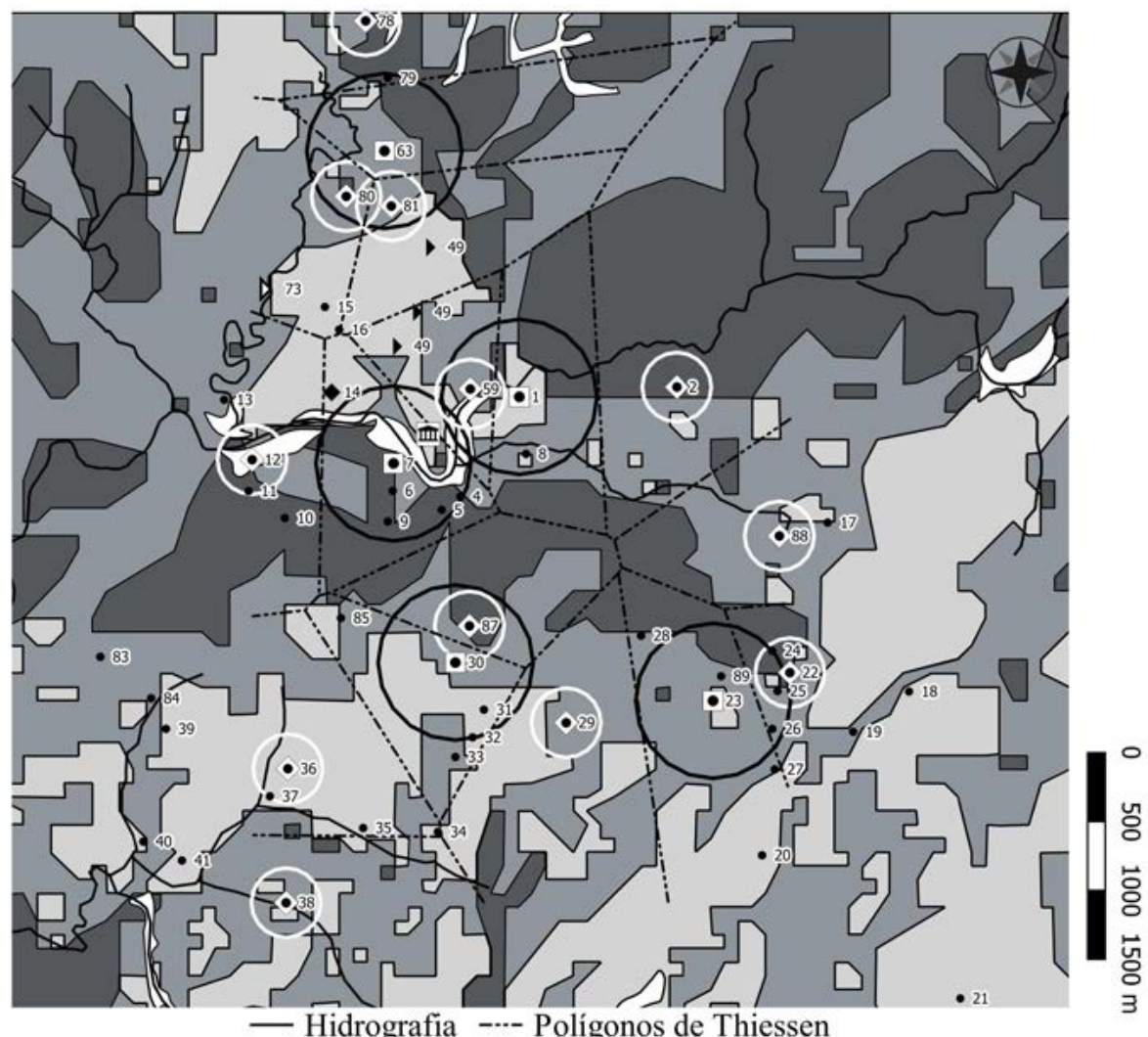

\section{Classes}

$\square$ Uso potencial intensivo

Uso potencial extensivo máximo

Uso potencial extensivo médio

Uso potencial nulo

\author{
Sítios arqueológicos \\ IIII Igaedis \\ - Villa \\ - Casal
}

- Tugurium

D Barragem

- Caleiras

- Forno Cerâmico

Figura 6. Buffers e polígonos de Thiessen calculados em torno de villae e casais (S. Lacerda).

o território de exploração de alguns casais (os quais, por este motivo, poderão antes corresponder a anexos destas villae); ii) ao mesmo tempo, relacionam-se estreitamente com a cidade (as villae $\mathrm{n}^{\circ} 1$ e 7 , esta última objeto de sondagens [Almeida 1977: 16], poderão até ser consideradas suburbanas) e com a principal via, como veremos, que cruzava (de sul para norte) este território; iii) as extremas comuns aos polígonos das várias villae coincidem com uma faixa situada a sul de Igaedis classificada com uso potencial nulo; esta constatação parece reforçar a ideia de que o povoamento rural em torno da cidade romana se instalou estrategicamente nas zonas de maior aptidão agrícola, enquanto os limites das suas propriedades coincidem com as zonas sem aproveitamento agrícola (estas, na atualidade, coincidem em parte com aquelas que não foi possível prospetar por estarem incultas e invadidas por matos).

\subsection{CASAIS}

Doze dos assentamentos rurais identificados foram classificados como casais ${ }^{12}$. O tipo de análise espacial

${ }^{12}$ Talvez alguns destes sítios se pudessem classificar como granjas: estas distinguiam-se das villae por serem propriedade de famílias menos abastadas; essa condição social começava por se revelar numa área residencial mais modesta, desenhada por paredes de alvenaria, não rebocadas, e pavimentos térreos; o conjunto das dependências agropecuárias de uma granja não atingia a amplitude da pars rustica de uma villa; a propriedade explorada seria menor (Carvalho 2007a e 2007b). Neste sentido, estas granjas, a partir dos vestígios de superfície, nem sempre serão facilmente distinguíveis dos casais (ou mesmo das villae, se neste caso as granjas assumirem maiores proporções).

Os sítios que integram esta categoria são os seguintes: $n^{\circ} 2$ : Corxo; $n^{\circ}$ 12: Queijeira das Corgas; $n^{\circ} 22$ : Valados 1,2 e $3 ; n^{\circ}$ 29: Terra do João Rodrigues; $n^{\circ} 36$ : Azinhal Velho 5; $n^{\circ} 38$ : Espadaneira; $n^{\circ}$ 59: Tapada do Rei Vamba / Tapada do Jardim 
adotado para as villae foi também aplicado aos casais. Num primeiro momento, foram definidos buffers para cada um dos casais. O cálculo da propriedade não teve por base (ao contrário do que sucedeu nas villae) a proposta defendida por Jorge de Alarcão, rondando os c. 5 hectares (1999: 34). Embora anteriormente tenha sido assumida esta hipótese, agora, depois de revistos os dados, e tendo inclusivamente em conta que alguns poderão ser núcleos de maior entidade (tipo granja), consideramos mais ajustado propor para estes sítios, como hipotética área fundiária, c. 20 hectares.

A partir dos buffers representados no mapa da figura 6 , sintetizamos na tabela da figura 7 a distribuição das terras pelas propriedades hipotéticas dos casais.

Entre os doze casais verifica-se uma característica comum: todos eles incluem no seu domínio de influência terras aptas para uma agricultura de tipo extensivo, sendo este tipo de terras maioritário em oito destas propriedades $\left(\mathrm{n}^{\mathrm{o}} 22,29,36,38,59,80,81\right.$ e 88$)$. Em termos de variabilidade de terras, apenas três deles $\left(\mathrm{n}^{\mathrm{o}}\right.$ 12,59 e 78) abrangem áreas propícias para agricultura de tipo intensivo e nulo, simultaneamente; por outro lado, em cinco destes casais a variabilidade é assegu-

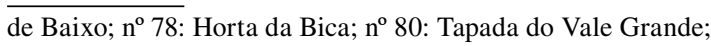
$\mathrm{n}^{\circ}$ 81: Alto do Estacal / Bouchas / Terra da Maria do Campo; $\mathrm{n}^{\circ}$ 87: Pedra Furada; no 88: Moroços / Terra das Perdizes. rada apenas pela presença de terras de uso extensivo e nulo (n' $2,22,80,87$ e 88$)$.

Face à menor área de influência estipulada para os casais, seria de esperar que a distribuição da terra no interior dos respetivos buffers fosse menos diferenciada. No entanto, tal não se verifica: apenas quatro dos doze casais $\left(\mathrm{n}^{\circ} 29,36,38\right.$ e 81$)$ se restringem a um tipo de uso potencial - o extensivo, variando entre o máximo e o médio, mas tendo o uso médio mais expressão que o máximo. Todos os outros incluem, no seu domínio de influência, diversidade de usos potenciais $\left(\mathrm{n}^{\mathrm{o}} 2,12,22,59,78,80,87\right.$ e 88$)$.

Nos casos em se assiste a uma vinculação mais restrita a certo tipo de terra, esta talvez se explique no quadro de uma especialização económica e funcional diferenciada a que determinados casais estariam sujeitos. Em alguns deles, a criação de gado e a pastorícia poderiam prevalecer relativamente a outras atividades - convém a este propósito referir que a pecuária não exigiria um investimento tão continuado, nem tanta mão de obra, como aconteceria com a generalidade das atividades agrícolas.

Em torno de Igaedis, como verificámos anteriormente, as áreas aptas para a agricultura de tipo intensivo são muito escassas. Todavia, três casais $\left(\mathrm{n}^{\circ} 12\right.$, 59 e 78) localizam-se nessas manchas. Se a qualidade dessas terras nos ajudará a compreender melhor a

\begin{tabular}{|c|c|}
\hline $\begin{array}{c}\text { Casais } \\
\left(\text { (n. } .^{\circ}\right.\end{array}$ & Domínio de influência \\
\hline 2 & $\begin{array}{l}69 \% \text { de terras de uso potencial nulo; } 27 \% \text { de terras de uso potencial extensivo médio; } 4 \% \text { de terras de } \\
\text { uso potencial extensivo máximo. }\end{array}$ \\
\hline 12 & $\begin{array}{l}35 \% \text { de terras de uso potencial intensivo; } 31 \% \text { de terra de uso potencial nulo; } 30 \% \text { de terras de uso } \\
\text { potencial extensivo médio; } 4 \% \text { de terras de uso potencial extensivo máximo }\end{array}$ \\
\hline 22 & $\begin{array}{l}51 \% \text { de terras de uso potencial extensivo médio; } 37 \% \text { de terras de uso potencial nulo; } 12 \% \text { de terras } \\
\text { de uso potencial extensivo máximo }\end{array}$ \\
\hline 29 & $81 \%$ de terras de uso potencial extensivo médio; $19 \%$ de terras de uso potencial extensivo máximo \\
\hline 36 & Só possui terras de uso potencial extensivo máximo \\
\hline 38 & $72 \%$ de terras de uso potencial extensivo médio; $28 \%$ de terras de uso potencial extensivo máximo \\
\hline 59 & $\begin{array}{l}50 \% \text { de terras de uso potencial extensivo médio; } 28 \% \text { de terras de uso potencial extensivo máximo; } \\
18 \% \text { de terras de uso potencial intensivo; } 4 \% \text { de terras de uso potencial nulo. }\end{array}$ \\
\hline 78 & $\begin{array}{l}43 \% \text { de terras de uso potencial nulo; } 42 \% \text { de terras de uso potencial extensivo médio; } 12 \% \text { de terras de } \\
\text { uso potencial intensivo; } 3 \% \text { de terras de uso potencial extensivo máximo. }\end{array}$ \\
\hline 80 & $\begin{array}{l}91 \% \text { de terras de uso potencial extensivo médio; } 5 \% \text { de terras de uso potencial nulo; } 4 \% \text { de terras de } \\
\text { uso potencial extensivo máximo. }\end{array}$ \\
\hline 81 & $68 \%$ de terras de uso potencial extensivo médio; $32 \%$ de terras de uso potencial extensivo máximo. \\
\hline 87 & $56 \%$ de terras de uso potencial nulo; $44 \%$ de terras de uso potencial extensivo médio. \\
\hline 88 & $\begin{array}{l}87 \% \text { de terras de uso potencial extensivo médio; } 11 \% \text { de terras de uso potencial extensivo máximo; } 2 \% \\
\text { de terras de uso potencial nulo. }\end{array}$ \\
\hline
\end{tabular}

Figura 7. Usos potenciais da terra contidos na área de influência dos casais (S. Lacerda). 
presença de duas villae nas proximidades $\left(\mathrm{n}^{\mathrm{o}} 1 \mathrm{e}\right.$, sobretudo, $\mathrm{n}^{\mathrm{0}} 7$ ), a apropriação destas terras por parte de um casal poderá ser mais difícil de justificar - haverá neste caso alguma relação de dependência direta (arrendamento) com outro núcleo de maior entidade? Ou será antes um indício de que estes sítios, e sobretudo o sítio da Queijeira das Corgas ( $\left.\mathrm{n}^{\circ} 12\right)$, possa ser uma unidade agrícola mais importante do que um casal?

A abordagem ao povoamento que efetuámos não inscreve necessariamente os casais na dependência direta das villae. A disposição espacial entre os casais é espaçada e independente (exceto a dos casais $n^{\circ} 80$ e 81). A disposição destes relativamente às villae é, na maioria dos casos, distanciada e intervalada. Porém, e como já antes referimos, existem casos de sobreposição: a villa $\mathrm{n}^{\circ} 1$ e o casal $\mathrm{n}^{\circ} 59$; a villa $\mathrm{n}^{\circ} 23$ e o casal $\mathrm{n}^{\circ} 22$; a villa $\mathrm{n}^{\circ} 30$ e o casal $n^{\circ} 87$; e a villa $\mathrm{n}^{\circ} 63$ e os casais $\mathrm{n}^{\circ}$ 80 e 81 . Por outro lado, os casais parecem relegados para uma posição periférica relativamente à cidade e ao trajeto da via imperial (exceto o casal no 29,59 e 87).

As relações de dependência que constatámos entre villae e tuguria, através do exercício dos polígonos de Thiessen, parecem ser de natureza idêntica àquelas que observamos entre casais e tuguria:

a) os tuguria $\mathrm{n}^{\circ} 10,11$ e 13 e o casal $\mathrm{n}^{\mathrm{o}} 12$, embora o buffer apenas abarque o tugurium $\mathrm{n}^{\circ} 11$;

b) os tuguria $\mathrm{n}^{\mathrm{o}} 18,19,24,25$ e 26 e o casal n $\mathrm{n}^{\mathrm{o}} 22$, enquanto o buffer inclui apenas os tuguria $\mathrm{n}^{\circ} 24$ e 25;

c) os tuguria $\mathrm{n}^{\circ} 34,35$ e 37 e o casal $n^{\circ} 36$, sendo que o buffer apenas inclui este último;

d) o tugurium $\mathrm{n}^{\mathrm{o}} 79$ e o casal $\mathrm{n}^{\circ} 78$, ainda que afastado dos limites do buffer;

e) os tuguria $n^{\circ} 15$ e 16 e o casal $n^{\circ} 80$, apesar destes estarem muito afastados dos limites do buffer;

f) o tugurium $n^{\circ} 17$ e o casal $n^{\circ} 88$, não abrangido pelo buffer;

g) no caso dos casais $n^{\circ} 2,29,38,59,81$ e 87, tal como na villa 63 , parece não existir qualquer relação de dependência.

Temos vindo a associar às villae e aos casais/granjas os vários tuguria dos campos de Idanha. Tal não significa, porém, que este cenário de dependência fosse o único possível. A proximidade de alguns destes casebres relativamente à cidade poderá sugerir que os seus proprietários/usufrutuários residiam em Igaedis, podendo cultivar estreitas parcelas de terreno nos arredores da cidade, onde erguiam pequenas construções de apoio às atividades agrícolas. Nesta situação estão, sobretudo, os tuguria $\mathrm{n}^{\circ}$ 4, 5, 6, 8, 9, 15 e 16, localizados entre os 200 a 1100 metros da cidade. Alguns dos lugares de tipologia indeterminada deste catálogo que pontilhavam os arredores da cidade poderão igualmente corresponder a pequenos casebres.
Afastados da cidade, e sem que tenham nas imediações um núcleo tipo villa ou casal/granja do qual possam depender, encontram-se os tuguria $\mathrm{n}^{\circ} 21,39$, 40, 41, 83 e 83. Estes aparentes pequenos sítios estariam nas mãos de rendeiros de parcelas mais periféricas, propriedade de famílias mais abastadas que viviam nas villae ou na cidade? Ou, simplesmente, não se terá ainda descoberto um núcleo rural de maior envergadura do qual possam diretamente depender, dado que se situam em áreas de bom uso potencial de terra? Esta última hipótese também acaba por mostrar o potencial preditivo que um MUPT pode ter, auxiliando na seleção de futuras áreas a prospetar.

\section{A CIDADE E O POVOAMENTO RURAL: UMA INTERDEPENDÊNCIA NECESSÁRIA}

É sobretudo a partir do séc. I d.C. que a paisagem rural de Idanha ganha novos contornos. Igaedis constitui-se como capital de civitas em torno da mudança de era e, a par da construção do núcleo urbano e da delimitação do território da civitas, os campos conhecem uma nova ocupação (Carvalho 2009). Um novo padrão de povoamento rural implanta-se em terrenos até então, ao que tudo indica, desabitados (sem núcleos habitacionais dispersos). As mudanças fazem-se sentir não só na lógica locacional, mas também no parcelamento dos campos e nos cultivos - nomeadamente com a generalização da oliveira.

A partir da capital nasce uma rede de lugares que povoa intensamente o ager da civitas Igaeditanorum e que assume um carácter eminentemente agrícola. Entre o campo e a cidade estabelece-se uma permanente interdependência, assente numa lógica económica de produção e abastecimento. Esta estreita relação justificará uma maior densidade de sítios rurais nas imediações da cidade, ainda por cima estimulada pelos bons e raros terrenos favoráveis a uma agricultura de tipo intensivo existentes na área periurbana.

Outras construções relacionadas com a cidade foram igualmente erguidas nos seus arredores, como por exemplo a barragem da Ribeira de rio de Moinhos, a cerca de $1500 \mathrm{~m}$ para noroeste de Igaedis (Quintela et alii 1995: 92-94). Com uma albufeira com um volume de armazenamento na ordem dos $180.000 \mathrm{~m}^{3}$, terá sido muito provavelmente construída para abastecer o núcleo urbano, para além de poder contribuir para a irrigação dos campos vizinhos a jusante (terras de uso potencial extensivo máximo). O mesmo aconteceria com o forno cerâmico (escavado por Fernando de Almeida) instalado fora da cidade, talvez pertença de um residente urbano, uma vez que não tem claramente um núcleo rural associado. 


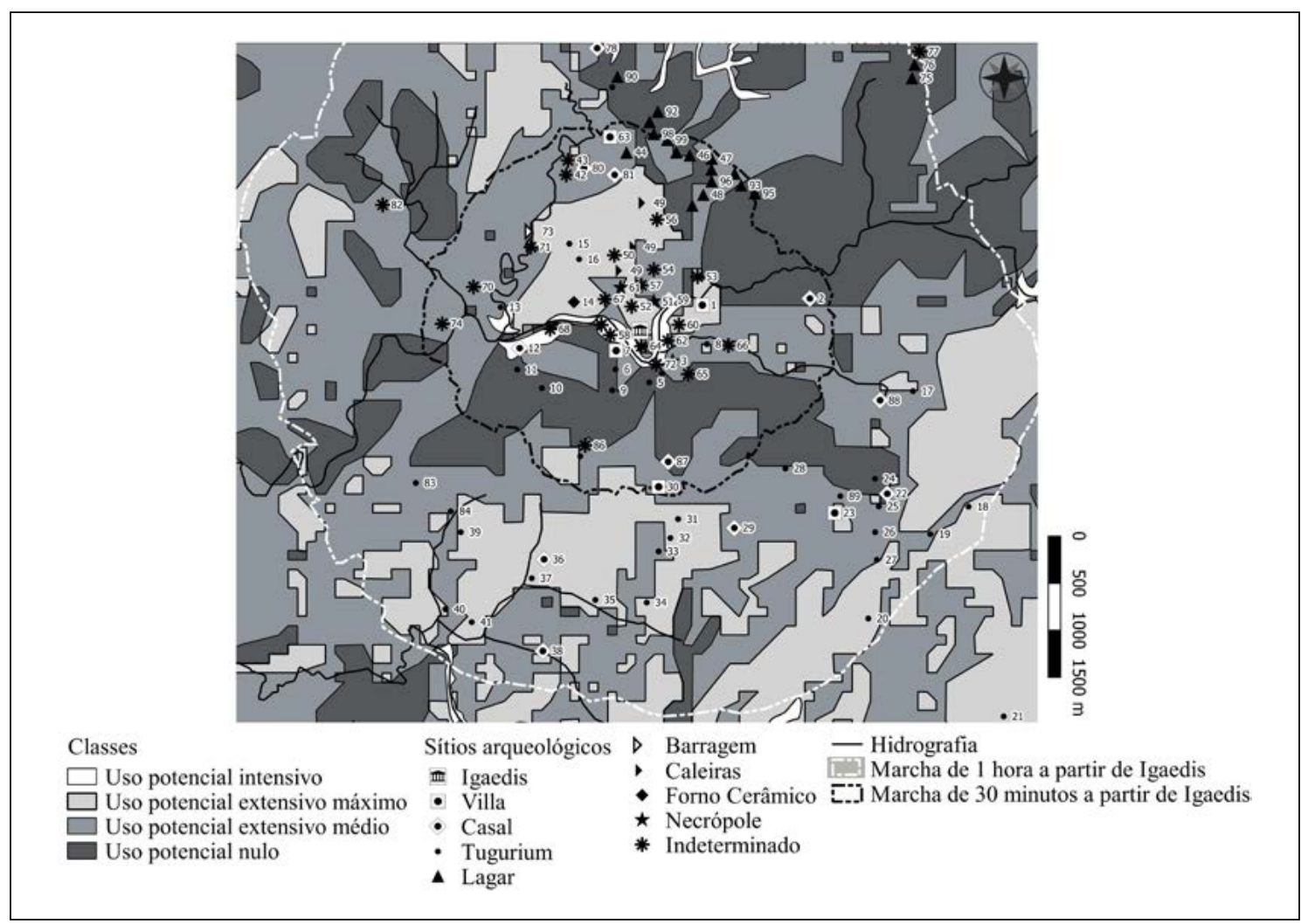

Figura 8. Territórios de marcha calculados a partir de Igaedis (S. Lacerda).

Foi também neste quadro de análise que calculámos os tempos de marcha a partir da sede de civitas. Ensaiámos dois limites de tempo/custo, respetivamente as isócronas de 30 e 60 minutos, contadas desde o fórum. O mapa da figura 8 permite-nos percecionar como o terreno, não muito acidentado, é favorável a essa dinâmica e mobilidade, uma vez que em apenas uma hora de caminhada é possível atingir, a partir de Igaedis, quase todos os sítios rurais aqui cartografados.

Esta rede de povoamento rural parece ganhar menos expressão à medida que nos afastamos da cidade capital, mas a sua densidade continua a ser notória. O facto de a área em estudo ser atravessada pela via imperial que ligava a capital da Lusitânia (Emerita) às civitates do interior norte da Lusitânia, passando o Tejo na Ponte de Alcântara e encontrando um importante ponto de paragem na capital da civitas Igaeditanorum, constitui um fator que só por si atrairia povoamento rural e facilitaria o acesso a Igaedis.

Na figura 9 desenhámos o trajeto dessa via entre Idanha-a-Velha e Alcafozes (lugar de achado de um miliário) ${ }^{13}$. Ao mesmo tempo, para confrontar também com a informação anterior, recorreu-se ao "Modelo de Acumulación de Desplazamiento Óptimo” (MADO), que permite calcular os traçados ótimos a partir de Igaedis, mas sem assinalar um destino. Este modelo é obtido a partir de uma superfície de fricção que define os custos de deslocação tendo por base o declive do terreno e a rede hidrográfica. A partir daí o algoritmo calcula os canais de irradiação mais favoráveis à marcha desde o ponto de partida, com base em funcionalidades utilizadas na hidrologia para o cálculo de redes de escoamento e respetivos caudais (Fábrega-Álvarez 2006: 8; Osório e Salgado 2018: 55). Esta projeção, tal como o mapa de usos potenciais da terra, pode assumir um valor preditivo para futuras prospeções, uma

13 Este traçado foi desenhado em 1990 de acordo com as informações então prestadas pelo Sr. Adelino Beatriz Ramos, grande conhecedor dos campos de Idanha e que acompanhou D. Fernando de Almeida nos trabalhos realizados na Egitânia nas décadas de 50 e 60 do séc. XX. Esse antigo caminho, ligando Idanha-a-Velha a Alcafozes (e cujo traçado se pode ainda observar na fotografia aérea de 1958), continuava ainda a ser percorrido pelas gentes da região na primeira metade do séc. XX. 
vez que há lugares dispersos pelo território que também podem ter surgido em função desses caminhos ótimos.

Com base na figura 9 conseguimos perceber que, a partir de Igaedis, existem dois corredores de alto fluxo para sul, sendo que um deles (o mais ocidental) parece coincidir, grosso modo, com o traçado da estrada romana proposto no trabalho realizado em 1991. Assim, este exercício SIG veio de algum modo corroborar essa anterior proposta decorrente dos trabalhos de campo.

A villa $\mathrm{n}^{\circ} 30$ encontra-se contígua a este traçado, enquanto o casal $n^{\circ} 29$ se situa nas imediações do se- gundo corredor (mais oriental). Para norte abrem-se também dois percursos com fluxo elevado, ao longo dos quais se localizam restos de antigas caleiras $\left(\mathrm{n}^{\circ}\right.$ 49), uma necrópole ( $\left.n^{\circ} 61\right)$ e a villa $n^{\circ} 63$. Por sua vez, a necrópole $\mathrm{n}^{\circ} 51$ encontra-se junto a um terceiro corredor, virado a nordeste, que se desdobra posteriormente em dois percursos de menor fluxo. Para leste, irradiam corredores de fluxo acumulado, curtos ou mais continuados, nas proximidades dos quais se encontra a necrópole $n^{\circ} 3$. Finalmente, para oeste, distinguem-se dois corredores de longo fluxo, um de cada lado do rio Ponsul. O casal $n^{\circ} 12$ fica justaposto ao trajeto da margem sul.

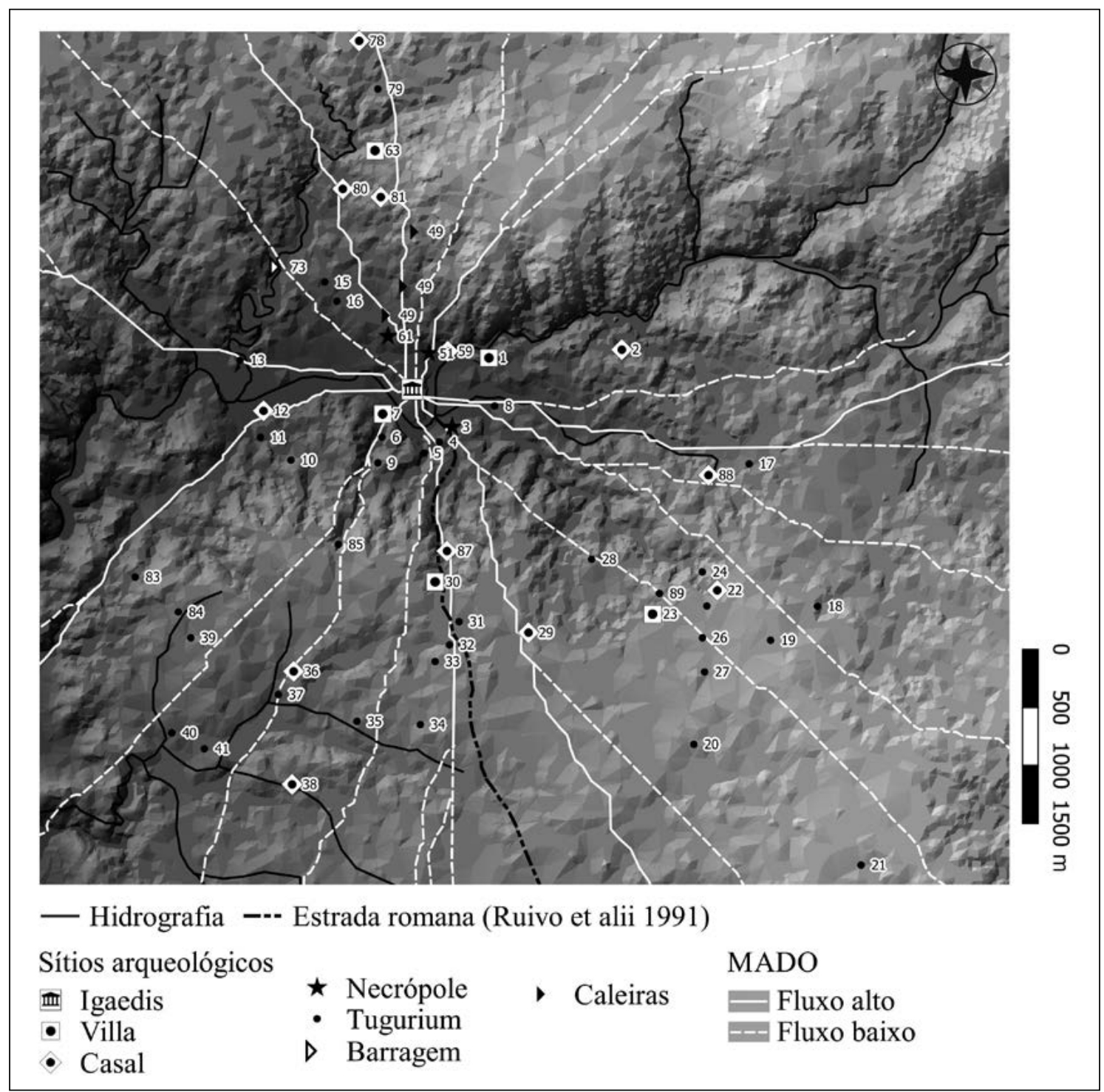

Figura 9. MADO calculado a partir de Igaedis e traçado da estrada romana proposto em 1991 (S. Lacerda). 
Praticamente todas as villae se situam nas proximidades destes corredores naturais. As villae $\mathrm{n}^{\circ} 30 \mathrm{e}$ 63 ficam junto a grandes fluxos acumulados, que correspondem ao trajeto imperial que atravessava este território; a villa $\mathrm{n}^{\circ} 7$ apanha um curto troço de elevado fluxo e de acesso rápido à cidade; a villa $\mathrm{n}^{\circ} 23$ encontra-se adjacente a um trajeto de baixo fluxo e somente a villa $\mathrm{n}^{\circ} 1$ se localiza numa posição mais distanciada.

Quanto aos casais, também eles, na sua maioria, parecem preferir zonas por onde se projetam corredores naturais de circulação. Assim, os casais da margem norte do Ponsul ( $n^{\circ} 59,78,80$ e 81 ) localizam-se todos em corredores de alto fluxo e rápido acesso à cidade, a sul, e na mesma posição privilegiada encontramos o casal $n^{\circ} 87$. Os casais $n^{\circ} 12$ e 29 encontram-se junto a corredores de fluxo acumulado radiais. O casal $n^{\circ} 36$ e 88 situa-se próximo de um trajeto de baixo fluxo, enquanto o casal $n^{\circ} 22$ se situa numa zona intermédia entre corredores. Já os casais $\mathrm{n}^{\circ} 2$ e 38 parecem preferir a proximidade das linhas de água relativamente aos caminhos de maior fluxo.

De um modo geral, podemos afirmar que era elevada a mobilidade pelas terras em redor da capital da civitas Igaeditanorum. As pessoas que habitavam estes núcleos rurais tinham acessos facilitados à cidade e ao restante povoamento disperso que se estabeleceu em torno dela.

\section{CONCLUSÃO}

As terras que desenham a paisagem do ager Igaeditanorum são terras vocacionadas sobretudo para uma agricultura extensiva, como aliás ainda hoje acontece. A agricultura intensiva é uma realidade circunscrita a áreas diminutas, praticamente cingida às terras baixas que acompanham as principais linhas de água. O MUPT mostra-nos que na zona periurbana de Igaedis existe um anel significativo de terras de uso potencial nulo, sobretudo a sul e a nascente, intercalado por uma faixa de terras com potencial intensivo (que ladeiam o rio Ponsul) e pela restante mancha de terras com potencial extensivo. Mais além desses ter-

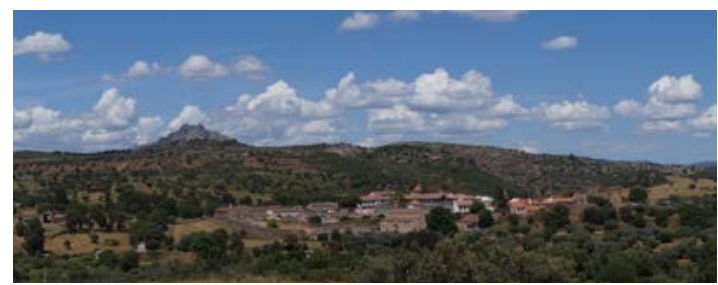

ritórios periurbanos dominam as terras de uso potencial extensivo, algumas destas classificadas pela prospeção intensiva como áreas vazias de povoamento, talvez ocupadas por campos de cereal ou por pastos, entre azinhais. Dentro da área acessível numa hora de marcha, desde a capital, existem sectores com solos de boa produtividade que não apresentam povoamento antigo conhecido, alguns por não terem ainda sido percorridos, mas que merecem futuras prospeções, nomeadamente no limite sudeste, na proximidade dos tuguria $\mathrm{n}^{\circ} 18,20$ e 21. Quanto às áreas sem povoamento nas manchas de solos menos vantajosos para o cultivo, esses vazios explicar-se-ão agora à luz deste MUPT.

A disposição dos núcleos rurais pelos campos de Idanha não é aleatória - houve obviamente fatores norteadores que a terão ditado. Parâmetros de ordem social, como a proximidade em relação à cidade ou mesmo à estrada, ajudarão a entender o modo como o povoamento rural se distribuiu com frequência por este território. Os laços familiares ou sociais (de vizinhança e cooperativos) também explicam algumas das concentrações de sítios em lugares mais afastados da cidade (para uma situação semelhante, cf. Carvalho et alii 2002). Todavia, as variáveis de ordem natural entre as quais se destaca o uso agrícola da terra - terão exercido certamente um peso decisivo na estruturação desse povoamento.

O MUPT em torno de Idanha-a-Velha ajudou-nos a abordar esta problemática. Revelou as diferentes classes de uso potencial da terra que compunham os fundi das villae e dos casais. Relembrou-nos que um fundus não era só composto por solos com boa capacidade de uso agrícola, mas também requeria zonas para pastagens (saltus) e bosques (silva). Este mosaico agrícola, silvícola e pastoril era essencial para se explorar uma ampla gama de recursos (nos quais se incluiriam também pequenas explorações mineiras). As villae poderiam ter grandes rebanhos de ovicaprinos, e isso exigia outro tipo de solos. O mesmo se passaria com os casais, podendo estes até assumir uma vocação eminentemente pastoril, procurando assim os designados "ambientes pastoris de montanha". As matas também eram essenciais (forneciam lenha e caça, mas

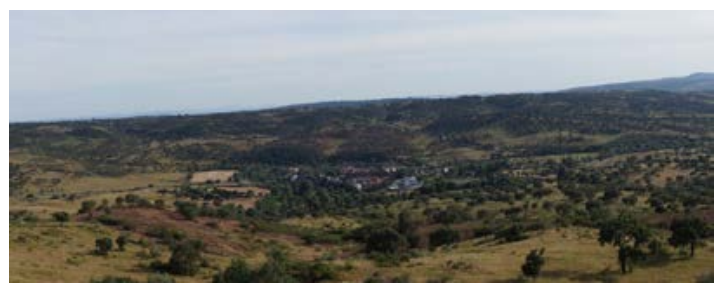

Figura 10. Os campos de Idanha-a-Velha: vistos de sul para norte (1) e de norte para sul (2) (P. C. Carvalho). 
também a cama e o alimento para o gado). Ou seja, um núcleo rural romano não procuraria ter no seu fundus um só tipo de terra, mas a proximidade a boas terras aráveis (assim como a disponibilidade de água) era fundamental. Neste mundo antigo, onde se inscrevia o interior da Lusitânia romana, o valor da terra era primordial.

Com a criação de um Mapa de Usos Potenciais da Terra e a sua aplicação a uma parte do território que compunha a civitas Igaeditanorum, demonstrou-se como este tipo de cartografia digital se pode traduzir numa ferramenta útil aos estudos de povoamento rural romano, permitindo-nos perceber padrões de assentamento, encontrar relações entre o povoamento e a terra ou mesmo prever a existência de potenciais sítios ainda não identificados em zonas de boa aptidão.

Os MUPT são também importantes desde uma perspetiva metodológica, já que devem ser encarados como um procedimento capaz de substituir a recorrente utilização na Arqueologia das Cartas de Capacidade de Uso do Solo. Estas últimas estão totalmente desajustadas às realidades agrícolas, económicas e tecnológicas do passado, já que foram criadas para serem analisadas à luz da atualidade.

Com esta abordagem cremos ter sido capazes de evidenciar as qualidades e potencialidades do MUPT, cruzando-o com outras ferramentas SIG (como os buffers, polígonos de Thiessen e as isócronas), revelando-se um instrumento preditivo de potenciais áreas merecedoras de prospeção e, sobretudo, como um meio de formulação de novas propostas teóricas que visem melhor compreender o funcionamento interno do povoamento rural, neste caso da civitas Igaeditanorum (Fig. 10).

\section{AGRADECIMENTOS}

Agradecemos a Brais Currás Refojos o apoio prestado para a produção deste MUPT e a Pedro Baptista por ter disponibilizado a superfície de fricção necessária a alguns dos cálculos aqui efetuados.

\section{ANEXO}

\begin{tabular}{|c|c|c|}
\hline & Topónimo & Tipologia \\
\hline 1 & Veiga I & Villa \\
\hline 2 & Corxo & Casal \\
\hline 3 & Olival do Salão & Necrópole \\
\hline 4 & Cabeço do Salão & Tugurium \\
\hline 5 & Furdas & Tugurium \\
\hline 6 & Furdões Velhos & Tugurium \\
\hline 7 & Olival das Almas & Villa \\
\hline 8 & $\begin{array}{l}\text { Queijeira do Vale do } \\
\text { Conde }\end{array}$ & Tugurium \\
\hline 9 & Cavaleiro & Tugurium \\
\hline 10 & Terra do Valentim & Tugurium \\
\hline 11 & Afesseirão das Corgas & Tugurium \\
\hline 12 & Queijeira das Corgas & Casal \\
\hline 13 & Beiradas & Tugurium \\
\hline 14 & Chão da Devesa & Forno cerâmico \\
\hline 15 & Terra da Nazaré 1 & Tugurium \\
\hline 16 & Terra da Nazaré 2 & Tugurium \\
\hline 17 & Lomba do Ouro & Tugurium \\
\hline 18 & Arraial da Gravaia 1 & Tugurium \\
\hline 19 & Arraial da Gravaia 2 & Tugurium \\
\hline 20 & Piçarreira & Tugurium \\
\hline 21 & Vale do Milhano & Tugurium \\
\hline 22 & Valados 1,2 e 3 & Casal \\
\hline 23 & Curral das Lagoas 2 & Villa \\
\hline 24 & Curral das Lagoas 3 & Tugurium \\
\hline 25 & Curral das Lagoas 4 & Tugurium \\
\hline 26 & Curral das Lagoas 5 & Tugurium \\
\hline 27 & Curral das Lagoa 6 & Tugurium \\
\hline 28 & Terra do Leitão & Tugurium \\
\hline 29 & $\begin{array}{l}\text { Terra do João } \\
\text { Rodrigues }\end{array}$ & Casal \\
\hline 30 & Quartos 1 & Villa \\
\hline 31 & Quartos 2 & Tugurium \\
\hline 32 & Azinhal Velho 1 & Tugurium \\
\hline 33 & Azinhal Velho 2 & Tugurium \\
\hline 34 & Azinhal Velho 3 & Tugurium \\
\hline 35 & Azinhal Velho 4 & Tugurium \\
\hline 36 & Azinhal Velho 5 & Casal \\
\hline
\end{tabular}




\begin{tabular}{|c|c|c|}
\hline & Topónimo & Tipologia \\
\hline 37 & Azinhal Velho 6 & Tugurium \\
\hline 38 & Espadaneira 3 & Casal \\
\hline 39 & Portal dos Carros & Tugurium \\
\hline 40 & Quinta da Granja 1 & Tugurium \\
\hline 41 & Quinta da Granja 2 & Tugurium \\
\hline 42 & Terra da Professora 1 & Indeterminado \\
\hline 43 & Terra da Professora 2 & Indeterminado \\
\hline 44 & $\begin{array}{l}\text { Queijeira da Terra } \\
\text { Grande }\end{array}$ & Lagar \\
\hline 45 & Serrinha 1 & Lagar \\
\hline 46 & Serrinha 2 & Lagar \\
\hline 47 & Barroca Funda II & Lagar \\
\hline 48 & Mina Velha I & Lagar \\
\hline 49 & $\begin{array}{c}\text { Carrascal da Serrinha } \\
\text { / Pombal / Horta da } \\
\text { Serra }\end{array}$ & Caleiras \\
\hline 50 & Olival da Entrada & Indeterminado \\
\hline 51 & $\begin{array}{l}\text { Chãozinho do } \\
\text { Espírito Santo }\end{array}$ & Necrópole \\
\hline 52 & $\begin{array}{l}\text { Chão do Espírito } \\
\text { Santo II }\end{array}$ & Indeterminado \\
\hline 53 & Carrascal Pequeno & Indeterminado \\
\hline 54 & $\begin{array}{c}\text { Chão da Raposa ou } \\
\text { dos Viveiros }\end{array}$ & Indeterminado \\
\hline 55 & Tapada Nova & Indeterminado \\
\hline 56 & Horta da Serra III & Indeterminado \\
\hline 57 & Cabeço dos Pinhos & Indeterminado \\
\hline 58 & $\begin{array}{c}\text { Chão da Fonte do } \\
\text { Arco ou Fonte da } \\
\text { Cruz }\end{array}$ & Indeterminado \\
\hline 59 & $\begin{array}{c}\text { Tapada do Rei Vamba } \\
\text { / Tapada do Jardim de } \\
\text { Baixo }\end{array}$ & Casal \\
\hline 60 & Cabeço da Forca & Indeterminado \\
\hline 61 & Tapada da Eira & Necrópole \\
\hline 62 & $\begin{array}{l}\text { Chão dos } \\
\text { Castanheiros }\end{array}$ & Indeterminado \\
\hline 63 & $\begin{array}{c}\text { Terra da Maria de } \\
\text { Campos }\end{array}$ & Villa \\
\hline 64 & Tapada das Quintas & Indeterminado \\
\hline 65 & $\begin{array}{l}\text { Carrascal I ou Alto do } \\
\text { Salão }\end{array}$ & Indeterminado \\
\hline 66 & Vale do Conde & Indeterminado \\
\hline 67 & Tapada dos Eucaliptos & Indeterminado \\
\hline
\end{tabular}

\begin{tabular}{|c|c|c|}
\hline & Topónimo & Tipologia \\
\hline 68 & Poço das Beiradas & Indeterminado \\
\hline 69 & Barroca Furada & Lagar \\
\hline 70 & $\begin{array}{l}\text { Terra das vacas ou } \\
\text { Pessegueiros }\end{array}$ & Indeterminado \\
\hline 71 & Curral ou Torrão & Indeterminado \\
\hline 72 & $\begin{array}{c}\text { Carrascal II ou Poço } \\
\text { dos Cágados }\end{array}$ & Indeterminado \\
\hline 73 & Curral ou Torreão & Barragem \\
\hline 74 & $\begin{array}{c}\text { Terra do Convento ou } \\
\text { Santíssimo }\end{array}$ & Indeterminado \\
\hline 75 & Afonseanes 2 & Lagar \\
\hline 76 & Afonseanes 3 & Lagar \\
\hline 77 & Afonseanes 4 & Indeterminado \\
\hline 78 & Horta da Bica & Casal \\
\hline 79 & Horta da Viúva & Tugurium \\
\hline 80 & $\begin{array}{l}\text { Tapada do Vale } \\
\text { Grande }\end{array}$ & Casal \\
\hline 81 & $\begin{array}{l}\text { Alto do Estacal / } \\
\text { Bouchas / Terra da } \\
\text { Maria do Campo }\end{array}$ & Casal \\
\hline 82 & Convento & Indeterminado \\
\hline 83 & Cucos 1 & Tugurium \\
\hline 84 & Cucos 2 & Tugurium \\
\hline 85 & Chão de Cima & Tugurium \\
\hline 86 & Furdas da Cardeira & Indeterminado \\
\hline 87 & Pedra Furada & Casal \\
\hline 88 & $\begin{array}{l}\text { Moroços / Terra das } \\
\text { Perdizes } \\
\end{array}$ & Casal \\
\hline 89 & Alagoas 2 & Tugurium \\
\hline 90 & Horta da Viúva & Lagar \\
\hline 91 & Cantarinhas 1 & Lagar \\
\hline 92 & $\begin{array}{l}\text { Caminho para o } \\
\text { Monte Canhão }\end{array}$ & Lagar \\
\hline 93 & Barroca Grande 2 & Lagar \\
\hline 94 & Barroca Grande 1 & Lagar \\
\hline 95 & Barroca Grande 3 & Lagar \\
\hline 96 & Funda & Lagar \\
\hline 97 & Mina Velha 2 & Lagar \\
\hline 98 & Bigorna & Lagar \\
\hline 99 & Bigorna 2 & Lagar \\
\hline
\end{tabular}

Figura 11. Listagem dos sítios arqueológicos identificados (S. Lacerda). 


\section{BIBLIOGRAFÍA}

Alarcão, J. de 1998: “A paisagem rural romana e altomedieval em Portugal", Conimbriga XXXVII, 98-119. https://doi.org/10.14195/1647-8657_37_4

Alarcão, J. de 1999: "Os arredores das cidades romanas em Portugal”, Archivo Español de Arqueología 72, 31-37. https://doi.org/10.3989/aespa.1999. v72.294

Almeida, F. de 1977: Ruínas de Idanha-a-Velha: $\mathrm{Ci}$ vitas Igaeditanorum. Egitania: Guia para o visitante, Lisboa.

Baptista, J. 1998: Carta Arqueológica da freguesia de Idanha-a-Velha, Vila Velha de Rodão.

Carvalho, P. C. 2004: Sobre o processo de identificação e classificação de sítios rurais no Portugal romano. $O$ Passado em cena: narrativas e fragmentos (Miscelânea oferecida a Jorge de Alarcão), Coimbra - Porto, 121-140.

Carvalho, P. C. 2007a: Cova da Beira: ocupação e exploração do território na Época Romana, Fundão - Coimbra.

Carvalho, P. C. 2007b: “Terlamonte I (Teixoso, Covilhã): uma quinta romana no interior norte da $\mathrm{Lu}-$ sitania", Conimbriga XLVI, 207-250. https://doi. org/10.14195/1647-8657_46_9

Carvalho, P. C. 2009: "O forum dos Igaeditani e os primeiros tempos da civitas Igaeditanorum", Archivo Español de Archeología 82, 115-131. https:// doi.org/10.3989/aespa.082.009.005

Carvalho, P. C., Ribeiro, C. A., Silva, R. C. da e Almeida, S. O. 2002: "Povoamento rural romano ao longo da Ribeira da Meimoa - Fundão (1. ${ }^{\text {a }}$ campanha de prospecção intensiva)", Conimbriga 41, 127-152. https://doi.org/10.14195/16478657_41_5

Criado Boado, F. 1999: Del terreno al espacio: planteamientos y perspectivas para la Arqueología del Paisaje, Santiago de Compostela.

Currás Refojos, B. X. 2014: "Mapa de usos potenciales de la tierra de Galicia. Una perspectiva arqueológica”, Trabajos de Prehistoria 71, 1, 23-41. https:// doi.org/10.3989/tp.2014.12122

Fábrega-Álvarez, P. 2006: "Moving without destination. A theoretical, GIS-based determination of routes (optimal accumulation model of movement from a given origin)", Archaeological Computing Newsletter 64, 7-11.

Fábrega-Álvarez, P., Parcero Oubiña, C. e Méndez Santiago, P. 2005: Alén dos castros de O Neixón: análise dixital dunha paisaxe arqueolóxica, X. M. Ayán Vila (coord.), Os castros de Neixón: recuperación dendê a Arqueoloxía dun espácio social e patrimonial, Noia, 247-287.
Henriques, F., Caninas, J. C., Chambino, M. e Camisão, V. 2008: "Cartografia arqueológica da freguesia de Monsanto (Idanha-a-Nova)", AÇAFA OnLine 1, 2-14.

Lacerda, S. 2018: "Usos potenciais da terra na antiguidade como alternativa às representações cartográficas dos solos existentes em Portugal. O caso da civitas Igaeditanorum (Idanha-a-Velha)", Estudos do Quaternário 19, 83-94.

Mano, A. 2012: Guia de Introdução ao Quantum GIS (QGIS), Mértola.

Orejas Saco del Valle, A. 1995: Del "marco geográfico" a la Arqueología del paisaje. La aportación de la fotografía aérea, Madrid.

Orejas Saco del Valle, A. 1996: Estructura social y territorio. El impacto romano en la cuenca noroccidental del Duero, Anejos de Archivo Español de Arqueología XV, Madrid.

Orejas Saco del Valle, A. 2006: "Arqueología de los paisajes agrarios e historia rural", Arqueología Espacial, 26, 7-19.

Osório, M. e Salgado, T. 2018: "A abordagem SIG ao Vale do Tua: Uma experiência inovadora", P. C. Carvalho, L. F. Coutinho e J. N. Marques (coords.), Estudo Histórico e Etnológico do Vale do Tua. Aproveitamento hidroelétrico de Foz Tua. Concelhos de Alijó, Carrazeda de Ansiães, Mirandela, Murça e Vila Flor, Porto, 4-59.

Parcero Oubiña, C. 2002: La construcción del paisaje social en la Edad del Hierro del Noroeste Ibérico, Ortegalia (Monografía de Arqueologia, Historia y Patrimonio) 1, Ortigueira.

Quintela, A. C., Cardoso, J. L. e Mascaranhas, J. 1995: "Barragens romanas do distrito de Castelo Branco e barragem de Alferrarede", Conimbriga XXXIV, 75-127. https://doi.org/10.14195/1647-8657_34_3

Reis, M. P. M. dos 2013: "Entre Monfortinho e Castelo Branco: sítios arqueológicos romanos ao longo de um projecto rodoviário (IC31)", J. Jiménez Avila, M. Bustamante-Álvarez y M. García Cabezas (coords.), VI Encuentro de Arqueología del Suroeste Peninsular, Villafranca de los Barros, 1804-1830.

Romero Perona, D. 2015: Territorio y formaciones sociales en la zona astur-lusitana del Duero, València.

Wheatley, A. e Gillings, M. 2002: Spatial technology and archaeology: the archaeology applications of GIS, London-New York.

Recibido: 31-05-2018 Aceptado: 11-10-2018 